Supplement of Ocean Sci., 10, 1047-1063, 2014

http://www.ocean-sci.net/10/1047/2014/

doi:10.5194/os-10-1047-2014-supplement

(C) Author(s) 2014. CC Attribution 3.0 License.

(c) (i)

Ocean Science

Supplement of

\title{
Chemical and physical transformations of mercury in the ocean: a review
}

N. Batrakova et al.

Correspondence to: N. Batrakova (batrakova.nv@gmail.com) 
1 Table S1. DGM Concentrations in Seawater.

\begin{tabular}{|c|c|c|}
\hline Location & Concentration, fM & Reference \\
\hline North Pacific & $30-90$ & Laurier et al. (2003) \\
\hline South and equatorial Pacific Ocean & $60-200$ & Laurier et al. (2003) \\
\hline South and equatorial Pacific Ocean & $60-140$ & Kim and Fitzgerald (1986) \\
\hline Equatorial Pacific & $50-225$ & Kim and Fitzgerald (1986) \\
\hline Equatorial Pacific & $15-690$ & Mason and Fitzgerald (1993) \\
\hline Equatorial Pacific & $40-325$ & Mason and Fitzgerald (1993) \\
\hline North Atlantic Ocean & $100-720$ & Mason et al. (1998) \\
\hline North Atlantic Ocean & $150-1500$ & Mason et al. (1998) \\
\hline North Atlantic Ocean & $28-89$ & Andersson et al. (2011) \\
\hline South Atlantic Ocean & $400-2000$ & Mason and Sullivan (1999) \\
\hline South and Equatorial Atlantic Ocean & $80-160$ & Mason et al. (2001) \\
\hline South and Equatorial Atlantic Ocean & 110 & Gardfeldt et al. (2003) \\
\hline Ireland, Mace Head & 107 & Gardfeldt et al. (2003) \\
\hline Mediterranean Sea, East & 170 & Gardfeldt et al. (2003) \\
\hline Mediterranean Sea, West & 75 & Gardfeldt et al. (2003) \\
\hline Tyrrhenian Sea & 95 & Gardfeldt et al. (2003) \\
\hline Mediterranean Sea, East & $201-221$ & Ferrara et al. (2003) \\
\hline Mediterranean Sea, West & 88 & Ferrara et al. (2003) \\
\hline Mediterranean Sea, West & 670 & Ferrara et al. (2003) \\
\hline Mediterranean Sea, West & $35-220$ & Cossa et al. (1997) \\
\hline Mediterranean Sea & $30-370$ & Horvat et al. (2003) \\
\hline Mediterranean Sea, West & 200 & Andersson et al. (2007) \\
\hline Tyrrhenian Sea & $100-300$ & Andersson et al. (2007) \\
\hline
\end{tabular}




\begin{tabular}{|c|c|c|}
\hline Location & Concentration, fM & Reference \\
\hline Ionian Sea & $80-330$ & Andersson et al. (2007) \\
\hline Adriaric Sea & $150-210$ & Andersson et al. (2007) \\
\hline Adriaric Sea, North & $350-1030$ & Andersson et al. (2007) \\
\hline Mediterranean Sea, Strait of Sicily & $100-140$ & Andersson et al. (2007) \\
\hline Mediterranean Sea, Strait of Messina & 220 & Andersson et al. (2007) \\
\hline Mediterranean Sea, Strait of Otranto & $130-180$ & Andersson et al. (2007) \\
\hline Mediterranean Sea & $120-190$ & Andersson et al. (2007) \\
\hline North Sea & $60-800$ & $\begin{array}{l}\text { Baeyens and Leermakers } \\
\text { (1998) }\end{array}$ \\
\hline North Sea & $150-370$ & Coquery and Cossa (1995) \\
\hline Baltic Sea & $70-100$ & Wangberg et al. (2001) \\
\hline Baltic Sea & $50-160$ & Kuss and Schneider (2007) \\
\hline Arctic Ocean, Beringia & $25-670$ & Andersson et al. (2008) \\
\hline Canada, Bay St.Francois & $105-720$ & Zhang et al. (2006) \\
\hline Japan, Tokyo Bay & $130-390$ & Narukawa et al. (2006) \\
\hline Black Sea, Coastal site & $251-893$ & Lamborg et al. (2008) \\
\hline Black Sea, Western Gyre & 206-1161 & Lamborg et al. (2008) \\
\hline Mediterranean Sea, Strait of Sicily & 2250 & Gardfeldt et al. (2003) \\
\hline France, Arcachon Bay, Aquitaine & $25-960$ & Bouchet et al. (2011) \\
\hline USA, Chesapeake Bay & $100-30$ & Mason et al. (1999) \\
\hline USA, San Francisco Bay & $20-1780$ & Conaway et al. (2003) \\
\hline Brazil, Sepetiba Bay & $160-410$ & Boszke et al. (2002) \\
\hline Brazil, Sepetiba Bay & $50-550$ & Molisani et al. (2007) \\
\hline Global ocean (modelling) & 70 & Strode et al. (2007) \\
\hline
\end{tabular}




\begin{tabular}{|c|c|c|}
\hline Location & Concentration, fM & Reference \\
\hline Mediterranean Sea, summer & $130-370$ & Kotnik et al. (2007) \\
\hline Mediterranean Sea, spring & $110-310$ & Kotnik et al. (2007) \\
\hline $\begin{array}{l}\text { Mediterranean Sea, Tyrrhenian Sea, } \\
\text { near Livorno }\end{array}$ & $120-460$ & Fantozzi et al. (2007) \\
\hline $\begin{array}{l}\text { Mediterranean Sea, Coastal seawater } \\
\text { (Island of Corsica) }\end{array}$ & $50-580$ & Fantozzi et al. (2007) \\
\hline $\begin{array}{l}\text { Mediterranean Sea, Offshore } \\
\text { seawater }\end{array}$ & $50-110$ & Fantozzi et al. (2007) \\
\hline Mediterranean Sea, Lagoon water & $20-900$ & Fantozzi et al. (2007) \\
\hline Atlantic Ocean, shelf, August 2008 & $100-220$ & Soerensen et al. (2013) \\
\hline Atlantic Ocean, shelf, October 2009 & $66-114$ & Soerensen et al. (2013) \\
\hline Atlantic Ocean, September 2008 & $108-148$ & Soerensen et al. (2013) \\
\hline Atlantic Ocean, June 2009 & $113-127$ & Soerensen et al. (2013) \\
\hline Atlantic Ocean, September 2009 & $97-125$ & Soerensen et al. (2013) \\
\hline Atlantic Ocean, August 2010 & $162-230$ & Soerensen et al. (2013) \\
\hline Yellow Sea & $169-468$ & Ci et al.(2011) \\
\hline South China Sea & $107-256$ & Fu et al.(2010) \\
\hline North Atlantic subtropics & $30-85$ & Kuss et al.(2011) \\
\hline Northern tropics & $40-219$ & Kuss et al.(2011) \\
\hline Southern tropics & $10-130$ & Kuss et al.(2011) \\
\hline South Atlantic subtropics & $15-70$ & Kuss et al.(2011) \\
\hline North Atlantic midlatitudes & $15-35$ & Kuss et al.(2011) \\
\hline Southern Ocean & $100-310$ & Cossa etal. (2011) \\
\hline
\end{tabular}


1 Table S2. Total Mercury Concentrations in Seawater.

\begin{tabular}{|c|c|c|}
\hline Location & Concentration, $\mathrm{pM}$ & Reference \\
\hline North Atlantic Ocean & $0.8-4.0$ & Mason et al. (1998) \\
\hline Deep North Atlantic Ocean & $1.5-3.1$ & Mason et al. (1998) \\
\hline South and Equatorial Atlantic Ocean & $0.94-2.42$ & Mason and Sullivan (1999) \\
\hline South and Equatorial Atlantic Ocean & $1.2-4.6$ & Mason and Sullivan (1999) \\
\hline $\begin{array}{l}\text { North Atlantic, Celtic Sea, LDW } \\
\text { (lower deep water) }\end{array}$ & $1.73-2.19$ & Cossa et al. (2004) \\
\hline $\begin{array}{l}\text { North Atlantic, Celtic Sea, LSW } \\
\text { (Labrador sea water) }\end{array}$ & $1.34-2.60$ & Cossa et al. (2004) \\
\hline $\begin{array}{l}\text { North Atlantic, Celtic Sea, MIW } \\
\text { (Mediterranean intermediate water) }\end{array}$ & $1.20-2.88$ & Cossa et al. (2004) \\
\hline $\begin{array}{l}\text { North Atlantic, Celtic Sea, ISOW } \\
\text { (Iceland-Scotland overflow water) }\end{array}$ & $2.31-3.11$ & Cossa et al. (2004) \\
\hline North Atlantic, Celtic Sea & $1.5-2.7$ & Cossa et al. (2004) \\
\hline North Atlantic (Mediterranean Sea) & $1.13-2.01$ & Cossa et al. (1997) \\
\hline $\begin{array}{l}\text { Gibraltar, MOW (Mediterranean } \\
\text { outflow water) }\end{array}$ & $1.82-2.64$ & Cossa et al. (1997) \\
\hline Mediterranean Sea, West & $1.29-3.79$ & Cossa et al. (1997) \\
\hline Mediterranean Sea, West & $1.05-1.87$ & Horvat et al. (2003) \\
\hline Mediterranean Sea, West & $1.72-1.93$ & Horvat et al. (2003) \\
\hline North Pacific & $0.38-0.90$ & Laurier et al. (2004) \\
\hline Black Sea, Coastal site & $1.6-7.6$ & Lamborg et al. (2008) \\
\hline Black Sea, Western Gyre & $1.9-11.8$ & Lamborg et al. (2008) \\
\hline Mediterranean Sea, summer & $0.84-2.08$ & Kotnik et al. (2007) \\
\hline Mediterranean Sea, spring & $0.89-1.53$ & Kotnik et al. (2007) \\
\hline
\end{tabular}




\begin{tabular}{lll}
\hline Location & Concentration, pM & Reference \\
\hline Mediterranean Sea, Strait of Sicily & 3.55 & Kotnik et al. (2007) \\
Mediterranean Sea (average) & $1.25-1.75$ & Rajar et al. (2007) \\
Atlantic Ocean, shelf, August 2008 & $1.8-4.7$ & Soerensen et al. (2013) \\
Atlantic Ocean, shelf, October 2009 & $0.58-2.32$ & Soerensen et al. (2013) \\
Atlantic Ocean, September 2008 & 0.63 & Soerensen et al. (2013) \\
Atlantic Ocean, September 2009 & 0.85 & Soerensen et al. (2013) \\
Atlantic Ocean, August 2010 & $1.2-1.6$ & Soerensen et al. (2013) \\
South China Sea & $4.5-7.5$ & Fu et al. (2010) \\
Southern Ocean & $0.63-2.76$ & Cossa etal. (2011) \\
\hline
\end{tabular}

1 


\section{1}

2

\section{References}

Andersson, M.E., Gårdfeldt, K., Wängberg, I., Sprovieri, F., Pirrone, N., Lindqvist, O.:

Seasonal and daily variation of mercury evasion at coastal and off shore sites from the Mediterranean Sea, Marine Chemistry, 104, 214-226, 2007.

Andersson, M.E., Sommar, J., Gårdfeldt, K., Lindqvist, O.: Enhanced concentrations of dissolved gaseous mercury in the surface waters of the Arctic Ocean, Mar. Chem., 110, 190$194,2008$.

Andersson, M.E., Sommar, J., Gårdfeldt, K., Jutterström, S.: Air-sea exchange of volatile mercury in the North Atlantic Ocean, Mar. Chem., 125, 1-7, 2011.

Baeyens, W., Leermakers, M.: Elemental mercury concentrations and formation rates in the Scheldt estuary and the North Sea, Mar. Chem., 60, 257-266, 1998.

Boszke, L., Głosińska, G., Siepak, J: Some Aspects of Speciation of Mercury in a Water 3 Environment, Polish Journal of Environmental Studies , 11, 4, 285-298, 2002.

Bouchet, S., Tessier, E., Monperrus, M., Bridou G., R., Clavier, J., Thouzeau, G. and 5 Amouroux, D.: Measurments of gaseous mercury exchanges at the sediment-water, water6 atmosphere and sediment-atmosphere interfaces of a tidal environment (Arcahon Bay, France), J. Environ. Monit., 13, 1351-1359, 2011.

Ci, Z.J., Zhang, X.S., Wang, Z.W., Niu, Z.C., Diao, X.Y., Wang, S.W.: Distribution and air9 sea exchange of mercury $(\mathrm{Hg})$ in the Yellow Sea, Atmos. Chem. Phys., 11, 2881-2892, doi:10.5194/acp-11-2881-2011, 2011.

1 Conaway, C.H., Squire, S., Mason, R.P., and Flegal, A.R.: Mercury speciation in San 2 Francisco Bay estuary, Marine Chemistry, 80, 199-225, 2003.

3 Coquery, M., Cossa, D.: Mercury speciation in surface waters of the North Sea, Neth. J. Sea 4 Res., 34 (4), 245-257, 1995.

5 Cossa, D., Martin, J. M., Takayanagi, K. and Sanjuan, J.: The distribution and cycling of 6 mercury species in the western Mediterranean, Deep Sea Res., Part II, 44(3-4), 721-740, 27997. 
1 Cossa, D., Cotte-Krief, M.H., Mason, R.P. and Bretaudeau-Sanjuan, J.: Total mercury in the 2 water column near the shelf edge of the European continental margin, Mar. Chem., 90, 21$329,2004$.

4 Cossa, D., Heimbürger, L.-E., Lannuzel, D., Rintoul, S.R., Butler, E.C.V., Bowie, A.R., 5 Averty, B., Watson, R.J., Remenyi, T.: Mercury in the Southern Ocean, Geochimica et 6 Cosmochimica Acta,75(14), 4037-4052, doi:10.1016/j.gca.2011.05.001, 2011.

7 Fantozzi, L., Ferrara, R., Frontini, F.P., and Dini, F.: Factors influencing the daily behaviour 8 of dissolved gaseous mercury concentration in the Mediterranean Sea, Mar. Chem., 107, 49 12, doi: 10.1016/j.marchem.2007.02.008, 2007.

10 Ferrara, R., Ceccarini, C., Lanzillotta, E., Gardfeldt, K., Sommar, J., Horvat, M., Logar, M., 11 Fajon, V., Kotnik, J.: Profiles of dissolved gaseous mercury concentration in Mediterranean Sea water, Atmospheric Environment, 37(S1), S82-S92, 2003.

Fu, X., Feng, X., Zhang, G., Xu, W., Li, X., Yao, H., Liang, P., Li, J., Sommar, J., Yin, R. and Liu, N.: Mercury in the marine boundary layer and seawater of the South China Sea: Concentrations, sea/air flux, and implication for land outflow, J. Geophys. Res., 115, D06303, doi:10.1029/2009JD012958, 2010.

Gårdfeldt, K., Sommar, J., Ferrara, R., Ceccarini, C., Lanzillotta, E., Munthe, J., Wängberg, I., Lindqvist, O., Pirrone, N., Sprovieri, F., Pesenti, E., Strömberg, D.: Evasion of mercury from coastal and open waters of the Atlantic Ocean and Mediterranean Sea, Atmospheric Environment 37 (Supplement 1), S73-S84, 2003.

Garratt, J.R.: The atmospheric boundary layer, Cambridge University Press, p. 316, 1992.

Horvat, M., Kotnik, J., Logar, M., Fajon, V., Zvonaric, T., Pirrone, N.: Speciation of mercury in surface and deep-sea waters in the Mediterranean Sea, Atmos. Environ., 37(S1), S93-S108, 2003.

Kim, J.P., Fitzgerald, W.F.: Air portioning of mercury in the Tropical Pacific Ocean, Science, 23, 1131-1133, 1986.

Kotnik, J., Horvat, M., Tessier, E., Ogrinc, N., Monperrus, M., Amouroux, D., Fajon, V., 28 Gibičar, D., Žižek, S., Sprovieri, F., and Pirrone, N.: Mercury speciation in surface and deep waters of the Mediterranean Sea, Mar. Chem., 107, 13-30, doi: 10.1016/j.marchem.2007.02.012, 2007. 
1 Kuss, J. and Schneider, B.: Variability of the Gaseous Elemental Mercury Sea-Air Flux of the

2 Baltic Sea, Environ. Sci. Technol., 41, 8018-8023, 2007.

3 Kuss, J., Zülicke, C., Pohl, C. and Schneider, B.: Atlantic mercury emission determined from 4 continuous analysis of the elemental mercury sea-air concentration difference within transects 5 between $50^{\circ} \mathrm{N}$ and $50^{\circ} \mathrm{S}$, Global Biogeochem. Cycles, 25, GB3021, 6 doi:10.1029/2010GB003998, 2011.

7 Lamborg, C.H., Yigiterhan, O., Fitzgerald, W.F., Balcom, P.H., Hammerschmidt, C.R., 8 Murray, J.: Vertical distribution of mercury species at two sites in the Western Black Sea, 9 Marine Chemistry, 111, 77-89, 2008.

10 Laurier, F. J. G., Mason, R. P., Whalin, L. and Kato, S.: Reactive gaseous mercury formation 11 in the North Pacific Ocean's marine boundary layer: A potential role of halogen chemistry, J. 12 Geophys. Res.,108(D17), 4529, 2003.

Laurier, F.J.G., Mason, R.P. , Gill, G.A. and Whalin, L.: Mercury distributions in the North Pacific Ocean: 20 years of observations, Mar. Chem., 90, 3- 19, 2004.

Mason, R.P. and Fitzgerald, W.F.: The distribution and cycling of mercury in the equatorial Pacific Ocean. Deep-Sea Research Part 1: Oceanographic Research Papers, Deep Sea Res., 40, 1897-1924, 1993.

Mason, R.P. and Sullivan, K.A.: The distribution and speciation of mercury in the south and equatorial Atlantic, Deep Sea Res., Part II, 46, 937- 956, 1999.

Mason, R.P., Rolfhus, K.R. and Fitzgerald, W.F.: Mercury in the North Atlantic, Mar. Chem., vol. 61, pp. 37-53, 1998.

Mason, R.P., Lawson, N.M., Lawrence, A.L., Leaner, J.J., Lee, J.G., Sheu, G.R.: Mercury in the Chesapeake Bay, Mar.Chem., 65, 77-96, 1999.

Mason, R.P., Lawson, N.M., Sheu, G.-R.: Mercury in the Atlantic Ocean: factors controlling air-sea exchange of mercury and its distribution in the upper waters Deep-Sea Res., Part 2, Top. Stud. Oceanogr., 48, 2829-2853, 2001.

Molisani, M.M., Kjerfve, B., Barreto, R., and Lacerda, L.D.: Land-sea mercury transport through a modified watershed, SE Brazil. Water research, 41, 1929-1938, 2007.

Narukawa, Masahiro; Sakata, Masahiro; Marumoto, Kohji; Asakura, Kazuo: Air-sea 
1 Rajar, R., Četina, M., Horvat, M., and Žagar, D.: Mass balance of mercury in the

2 Mediterranean Sea, Mar. Chem., 107, 89-102, doi:10.1016/j.marchem.2006.10.001, 2007.

3 Soerensen, A. L., Mason, R.P., Balcom, P. H., Sunderland, E.M.: Drivers of Surface Ocean

4 Mercury Concentrations and Air-Sea Exchange in the West Atlantic Ocean, Environ. Sci.

5 Technol., 47, 7757-7765, doi:10.1021/es401354q, 2013.

6 Strode, S.A., Jaegle’, L., Selin,, N.E., Jacob, D.J., Park, R.J., Yantosca, R.M., Mason, R.P., 7 Slemr, F.: Air-sea exchange in the global mercury cycle, Global Biogeochem. Cycl., 21, 82007.

9 Wängberg, I., Schmolke, S., Schager, P., Munthe, J., Ebinghaus, R., Iverfeldt, Å., Estimates 10 of air-sea exchange of mercury in the Baltic Sea, Atmospheric Environment, 35, 5477-5484, 112001.

12 Zhang, H.H., Poissant, L., Xu, X., Pilote, M., Beauvais, C., Amyot, M., Garcia, E., and 13 Laroulandie, J.: Air-water gas exchange of mercury in the Bay Saint Francois wetlands: 14 Observation and model parameterization, Journal of Geophysical Research, 111, d17307, 152006. 